\title{
Concerns of Organized Labor, 1902-18 \\ The Belleville Trades and Labor Assembly, Illinois
}

By

Mette Skakkebæk

Research Fellow, University of Copenhagen

The American labor movement and its engagement in party politics has been discussed by historians of different opinions since the end of the twenties, when Seymour Perlman wrote his book, $A$ Theory of the Labor Movement. The selection of this particular feature was of course based on the comparison with the European labor organizations that made forceful coalitions with the socialist parties during the same period. The image of absolute pragmatism of the Americans workers and lack of political engagement on ideological background has been under violent attack from historians since the end of the 1960's, causing considerable damage to this image. ${ }^{1}$

One approach that could shed some light on this disagreement, or rather the different appliance of emphasis, would be to carry out a local study and examine the development in one particular field at close range. It is the intention here to present a close-up portrait of a part of the American labor movement, based on the minutes of the biweekly meetings of the Belleville Trades and Labor Assembly, St. Clair county, in the state of Illinois. ${ }^{2}$

The various labor unions of Belleville were members of the assembly, which in 1911, in the middle of the period being considered here, represented 6000 organized workers. The miners showed the highest number of unions represented, and the foundry and the brewery workers had more than one union in the assembly. Apart from these, a broad variety of trade unions were members. Also the unskilled workers' organization, the Federal Labor Union, 
was represented. The minutes reflect the very formal democratic character of the assembly, but leaves the reactions of the members unconcealed. Two points in the meeting procedure were of special interest: the business agent's report of his activities and the communications, reporting the content of incoming and outgoing letters and the response of the audience to this correspondence, in addition to the list, entitled, "We Don't Patronize", with the names of firms and employers who in one way or another deserved tlie lable "unfair to organized labor".

This source material has been confronted with two questions: what were the main engagements of a locally restricted labor organization? and what was the attitude of the assembly towards party politics? The answer to the first question outlines the most important features of tlie activity of the period as a whole, and the second describes the changes in political attitudes over the years.

Typical conflicts for the Belleville assembly throughout this period were related to the organization of workers and the claim of the unions for job monopoly. The unions sent reports that expressed the problems arising out of this context for the individual workers, organized as well as unorganized.

In many cases the problems were solved between the workers themselves while the employer played a passive role. In certain periods employers showed hard resistance to organization and especially to acceptance of the closed shop.

In order to further union activity and to increase the general consciousness about the importance of organization, the unions took great trouble to secure that first of all their members did not buy goods in shops that sold merchandize not labelled as a product of union labor. The boycott was also used as a weapon in the struggle for the closed shop. Discussion with employers ran as follows:

They argued that this was a free country, free for their employees to join and not to join. We informed them that it was just as free to us laboring people and that we could buy lumber from their yards and we could refuse to buy from them, if they did not come clean with us. ${ }^{3}$

The unions also demanded that the preprocessed goods used in other kinds of manufacturing were to be declared a union product before the organized workers would handle them in the last part of the manufacturing process.

It was, however, not always easy to exercise discipline over the 
members to make the boycott effective. One brother complained that brother so and so's wife had repeatedly been seen shopping in the local Woolworth five and ten store, in spite of the assemblys ban on the company. The brother apologized and promised that it would never happen again. ${ }^{4}$ In 1913 , the business agent reported the following:

Regarding the notorious Stetson Hats so prdminently displayed in the windows of the Daenger company, I called upon the proprietor and told him that the assembly protested again the prominence given to these hats, and the apparent efforts to build a trade on these hats. At each meeting of the different locals the delegates to the assembly should remind their brothers of the unfair Stetson hats. Remember, they do not bear the label and should be avoided as though they were poison. ${ }^{5}$

The warning was repeated at several meetings.

The union label was a small symbol of the power of the organization, and the union label movement was very active. The campaign was also directed towards the public administration to demand use of union-labelled material exclusively and the acceptance of the closed shop in public construction work. Competition of free labor from the state penitentiary in cases of publicly paid work, caused several protest resolutions.

Some success was achieved from all the efforts. The names on the boycott lists changed at times and requests appeared that a particular employer or shop could now be considered as being fair to organized labor by and should be taken off the list.

At times the union label movement appeared close toidiosyncracy even to the unionists. On the inside cover of the minutes, written in pencil, the following piece of lyric was found:

For all his life in union shop

He earned his daily bread and so they found a union grave for him when he was dead. $\mathrm{He}$ had a union doctor and he had a union nurse A proper union coffin and a slap-up union hearse.

A union undertaker came a union parson prayed They put a union monument to mark where he was laid.
And it took just a union day to climb to the Golden Stair but down again he went for some non-union men were there. He dropped down to the other place and there produced his card the Devil pulled a serious face and scanned him good and hard Then smiled and said: I'm sorry, lad, But you have come a flop I thought that everybody knew this was an open shop.

The other major engagement of the assembly was to act as council for workers in wage conflicts. The means of the assembly were 
limited to persuasion and psychological pressure on the employers, and to moral and some financial support of the workers. The direct handling of wage problems took place between the individual trade unions and the employers, but causes and development of the strikers were closely followed by the assembly. During the first part of this period, strikes occurred mainly because of open-closed-shop controversies, later mostly as the result of wage conflicts. The course of strikes at Belleville are only described as peaceful, but a warning in the minute in 1910 against union men joining the newly founded militia, on grounds that such groups sooner or later would be used against strikers, indicates, that violence was not unknown. ${ }^{6}$

The defense of the closed shop, the effectuation of the boycott, and arbitration in wage conflicts provided the bulk of work for the assembly. The less demanding activities were the responsibilities of the entertainment committee, such as the Labor Day parades and picnics. The choice of speaker for Labor Day was always discussed carefully, and the decision was an expression of sympathy for the person as well as for the attitude he represented. Other social activities were Christmas dances and theater performances, some $\bar{r}_{\vec{r}}$ times to the financial benefit of striking unions, and arrangements of educational value, such as medical prevention courses, with lectures by the local physician. The entertainment committee also arranged protest meetings and demonstrations like those held for the McNamara brothers and other labor heroes of the times.

Concerning the immediate engagement in their own locality, the township of Belleville, the initiatives were not overwhelming in number, and they were of varying importance: protest against renewal of the franchise of the streetcar company, support fo requests to establish a municipal light plant, regulation of traffic through the mainstreet, while the pavement was being repaired. Considerable research had been going on in relation to a new form of city government; the assembly's legislative committee reported having been to the library to investigate the possibilities and had decided that the commission form should be encouraged. The removal of the gummachine, that stole the money from children, was recommended to the city council. A delegation of the assembly visited a member of the schoolboard, asking for free and uniform school books throughout the county and hopefully the state, and also that the union label should appear on all school books. This initiative was brought back to the Belleville assembly from the convention of the Illinois State Federation of Labor, where the problem 
was discussed and recommended for action. The union label was later reported as accepted, but the question of uniformity and payment was a more complicated affair. ${ }^{7}$

Many of the resolutions taken and sent off from the Belleville assembly had their origin in letters from the Illinois State Federation of Labor. The Illinois Federation was very active in conveying information to the unions, about which bills and legislative approaches to support. Besides distinctly labor legislative bills, other progressive reform ideas, as for example the initiative and referendum, were strongly supported by the Illinois Federation, as well as by the AFL. ${ }^{8}$

Similar information activity came from the national headquarters of the AFL. The topics recommended for supporting resolutions ranged from all the well-known labor conflicts during the period: Ludlow, Lawrence, the McNamara case, W. Virginia coal mines, the Danburry hatters (with one conspicous exception: Bill Haywood's imprisonment in Idaho), to a variety of more or less related issues in contemporary America. ${ }^{9}$ The Sherman law was sent out for a hearing, accompanied by specific questions; the Clayton bill for support, the immigration bill for protest, Victor Berger's old age pension bill for support. More unusual was the protest against the proposed treaty with Great Britain that was up in Congress in 1912, as, before WW I the AFL seldom took a stand on foreign policy issues. ${ }^{10}$

The minutes show the assembly's vivid interest in state and national labor organization and a sense of fellowship and loyalty towards them. The Belleville assembly supported most of the propositions they received from the superior organizations, with a few exceptions that were only filed in passive protest. The initiative to speak out on certain issues frequently came from outside, but the words of the resolutions were their own. One resolution that was markedly contrary to AFL policy, was a resolution condemning preparedness and militarism.11

Out of the reading of the Belleville assembly meeting reports a picture appears of the workers' perception of American society and their own place in it. It becomes clear that the Belleville unionists were quite pleased with the fundamental values and principles in the American society. They especially emphasized freedom, interpreted as freedom of organization, and they repeatedly referred to labor organization as being very American in contrast to the traditional arguments against unionism. They saw it as their right 
to protect their interest as a group by organizing. The following quotes express their views of the position of workers in society. The ad hoc committee set up to consider the need for medical insurance, as offered to the members by one of the local doctors reported:

First, it will reduce the cost of doctors and medicine, which all are now compelled to pay, and a thing that reduces the cost of the necessities of life to the working people, is equivalent to an advance in wages. Second, doctors have organized to better their particular class interests and the working people should do likewise by co-operating with one another. ${ }^{12}$

\section{Other resolutions had this wording:}

We as laboring men of a majority of the helpless public are vitally interested in the adoption of the initiative and the referendum; if these were adopted, some of the graft could be stopped in the legislature. ${ }^{13}$

Yes, the Sherman law could be so amended, as to extempt the labor organizations; the reason we favor this amendment is because labor organizations should not be classified as trusts. Labor organizations combine to better the conditions and raise the wages for the toiling millions, the majority of whom, now have a hard tussle to eke out an existence at the high costs of living. Whereas trusts are organized, to swell the fortunes of those who already have millions.

Later in the same set of questions from the National Civic Federation the following was asked, "In your judgment what caused or causes the present disturbed business conditions?" Answer: "Underconsumption and overproduction caused by lack of employment, on account of the introduction of labor saving machinery in the manner in which they are utilized". ${ }^{14}$

The Belleville trade unionists were not advocates of an overthrow of the American society, but they claimed recognition and some regulations of the economic conditions.

Their class consciousness was unquestionable and rested on a perception of American society as being divided into distinct economic classes, and of the exploitation of the working class. What made them different from the European workers generally is that the way in which they expected to abolish exploitation was through status equality and improvement of wages.

The scanning of the activities and interests of a forum of workers in a limited geographic area has been dealt with here as a whole by eliminating the time factor. The question of attitude towards political parties as remedies for realization of these expectations requires a description of change over the years. 
In a meeting report from 1904, the name of a political party is mentioned for the first time, in the following form: "The question of a debate on socialism is placed in the hands of the entertainment committee". ${ }^{15}$ This was the end of a debate in which the later prominent labor leader and secretary of the Socialist Party, Adolph Germer, from the United Mine Workers, had proposed that the assembly endorse the Socialist Party for the coming election. Later in the same year, the assembly received a letter from Samuel Gompers warning that the Western Federation of Miners was calling a convention to establish a new labor organization (later the IWW), but the letter did not provoke any comments from the assembly. ${ }^{16}$

In the 1908 election the AFL tried their first punish-yourenemies-reward-your-friends-campaign, and in this endorsed William Jennings Bryan for president. ISFL requested that all candidates be examined closely for their policy on labor questions, and the Belleville assembly wrote up the following motivation for their support to the democrats at the national level:

... Bryan has absolutely and unfalteringly pledged himself, if elected, to secure the rights of the toilers, to which they are so justly entitled. We therefore ... reiterate our declaration that although as organized workers, we are neither Democrats nor Republians, nor owe we allegiance to any political party whatsoever, we yet reiterate and reaffirm, to be our duty and the duty of all workers and friends of human liberty, to stand faithfully by our friends and elect them to oppose our enemies, whether they can be candidates for President for congress or for offices, whether executive, legislative or judiciary, and we pledge ourselves and call common people of our city and state to help carry into effect to laudable and enobling purposes for which the toilers struggle and aspire.17

However, the report from the succeeding meeting disclosed that the political action committee did not at all agree on who actually were labor's best friends. The committee then decided to set up written pledges that had to be signed by candidates who asked for the endorsement of the trade unions. This practise in the written form was later abandoned.

The campaign in 1908 was a failure at the national level, and had varying effect at the local level. In 1910, Adolph Germer received the assembly's endorsement as a candidate for the legislature, as the only person from the district to hold a union card. Also, the neighboring locals were requested to support Germer. At the following meeting the endorsement was criticized for covering Germer alone, "as in fact all candidates on the socialist ticket hold 
a union card. The subject was discussed at length and a motion passed, that this assembly endorse the entire socialist ticket and its candidates..."18

Some months later the assembly decided that no person could be the delegate of their union to the assembly if holding a political office. An amendment stated "unless they are also working in their trade". At about the same time another amendment was proposed, "... to prohibit the endorsing of political parties of their platform, except when the platform is the work of a duly appointed committee of the body". ${ }^{19} \mathrm{Bad}$ experiences of manipulation or political misuse of the assembly may lie behind this proposition. The proposition was voted down, but nevertheless the assembly did not again endorse any party, only individual candidates who had explained their attitude towards organized labor, and who had been accepted on that basis.

In 1913 a letter was received from the Socialist Party of America, requesting a protest against police brutality towards workers that had taken place in Michigan. The request was accepted, but the minutes recorded specifically that the delegates decided to write their own protest instead of endorsing that of the socialists. ${ }^{20}$

There was a marked change in the political activity of the assembly around 1912-13, in terms of an increase in letters to congressmen and senators, in Washington and in Springfield. All reform initiatives, especially in labor legislation demanded attention and participation, and the belief prevailed that the workers could do something to speed their efiectuation. The highest level of activity in politics was reached around the election in 1916. In that election the AFL endorsed Woodrow Wilson, but the presidential candidates are not mentioned in the meeting reports at all. The efforts of the Belleville unions were concentrated at the state and local level and their allegiance was plural: a member of the Federal Labor Union in the neighboring town of O'Fallon, was given support for his candidacy for the state legislature on the democratic ticket. One of the assembly's own officers for many years, representing the barbers' union, was supported as a candidate for the state legislature on the socialist ticket. The president of the Illinois miners asked for endorsement of the republican candidate for governor, and this was granted. ${ }^{21}$

Considerable energy and money were used that year to prevent the re-election of the republican state senator, James Rechtler, because of his voting record on labor legislative and labor support- 
ing bills. "He is on the unfair list, and we co-operate with other trade unions to defeat this enemy of labor. The poster will be posted throughout the entire 49th senatorial district" 22 . The members of the assembly were reminded to keep up the struggle against Rechtler among their members at every meeting, right till the last one, which was on the eve of the election. The result was a defeat - for the unions, and Rechtler was elected. ${ }^{23}$

The visit of Samuel Gompers as Labor Day speaker in 1916 can be seen as a symbol of the coincidence of attitude between the Belleville trade unionists and the AFL national leadership towards political parties, as practised in the 1916 election. The approaching war set off a development that for a while separated the two, but which gradually re-established a consensus.

The resolution on anti-militarism and rejection of the President's preparedness appeal, as well as distribution of an article entitled "The International War Trust", points towards reluctance to accept the government's foreign policy. ${ }^{24}$ In 1917, the assembly, for the first time and for obscure reasons, were not able to get access to the "Fair Grounds" for their Labor Day celebration; unsatisfactory explanations were given, which made the arranging committee talk about obstruction. With the war hysteria in mind it is not unlikely that a deliberate action lies behind the rejection of access. ${ }^{25} \mathrm{~A}$ month later the Illinois State Federation of Eabor asked the assembly for the names of five loyal Americans to be appointed members of the State Council of Defense and they were given. ${ }^{26}$ In January 1918, one of the officers of the assembly was elected chairman of the Eabor and Fraternal Society under the War Camp Community Recreation Fund. He conveyed an appeal to the Miners' unions to contribute at least $\$ 1$ per member. They replied that they would contribute one day's pay if their employer would contribute one day's profit. No more was heard of the matter. ${ }^{27}$ In February 1918, the assembly participated in the local Loyalty Demonstration Week, and the arrangements were reported in exuberant terms. ${ }^{28}$

In March 1918 the conversion was complete, marked by the decision to form a local branch of the American Alliance for Eabor and Democracy. At an extended meeting of the assembly, the president of the alliance in the neighboring town, "made an instructive and stirring patriotic address and explained the objects of the alliance and urged that we form a local alliance and that we continued our effortsuntil every man and woman in Belleville was 
a member. After a few remarks from others, a motion passed to proceed to make a temporary organization. Andrew Wilson, miner, member of the largest local union was elected by acclamation as chairman. Membership pledges were then presented and every member joined the new organization". The report of the meeting ends with the following words: "Every member agreed to a suggestion, there being no opposition, that each member constitute themselves as one of a committee of a whole, to work to the end of making this organization $100 \%$ in Belleville". ${ }^{29}$ From then on the Belleville assembly, including the stubborn miners, was as active a participant on the domestic war front as the administration could wish for.

To sum up: the largest part of the enthusiasm of the Belleville trade unionists was dedicated to organizational problems within their reach. But the majority of the initiatives to take stands on issues outside their limits, whether in labor organization at state and national level, occasionally also on local community issues, or in state and national politics, came from sources outside their ranks. Inspiration from the progressive reform ideas were rapidly accepted and supported in local and state legislation..$^{\mathbf{3 0}}$ The Illinois State Federation of Labor and, to a lesser extent the AFL, contributed to form the Belleville workers' stand on labor legislative issues and provided them with a view of labor organization throughout the country.

In party political affairs the attitude was more independent. There was a clear affiliation with the Socialist Party culminating nominally in the endorsement of the entire socialist ticket in 1910. The defection away from the Socialist party, even before the Socialist votes had culminated at the national level, may have several causes. My suggestion is that one factor was the socialist candidate, Adolph Germer, who somehow fell out with the assembly. Besides, the socialists may have pressed their point too hard. Gerrner went to work in the Socialist Party and was never again invited as speaker when he was in town, and was later referred to in chilly terms.

The assembly did not disassociate itself from their party connections after that election. Between 1912 and 1916 all the Labor Day speakers were Socialist Party members and Illinois State Federation officials; 3 of the four were also miners. The socialist, John Walker, received all the votes from the assembly whenever he was up for election as president of the Illinois State Federation of 
Labor. The President of the Belleville assembly from 1915-17 was a socialist; Victor Berger, socialist member of US congress, was used as the only reference in labor legislation, although five other members of congress were labor laders. But the excitement over and high expectations of the labor legislative activity set up by the AFL and ISFL attracted the Belleville workers and made them support the methods of the AFL.

Although hardly detectable in the minutes, there is some indication for internal disagreement on political matters. The miners in general seemed to have had more radical viewpoints, as did other individuals not grouped around any particular union. The slow conversion to the war may have been conditioned by this opposition, adhering to the socialist war resistance. Besides, St. Clair county had a high percentage of Germans, and the frequency of German names that appeared in the minutes are facts contributing to this development, and a combination of these two elements was hard to overcome. The pressure from public opinion and again the achievements of the labor movement during the war, however, caused a gradual change of mind. The alliance with the democrats and republicans rested purely on the credibility as a friend of labor's of the individual candidate.

The contribution of this sketch of a portrait to the general picture of the American labor movement would be that the workers were engaged in party politics, also with parties of an ideological character, such as the Socialist Party. But the basic aim was to promote trade unionism, and any party was just a vehicle for that purpose.

\section{$N O T E S$}

1 Selig Perlman, A Theory of the Labor Movement (1928). For summaries of the discussions, see review articles, like Robert Zieger, "Workers and Scholars: Recent Trends in American Labor Historiography," Labor History, Spring (1972) and Mette Skakkebæk, "Amerikansk socialisme og fagbevægelse $i$ begyndelsen af det 20.århundrede," Dansk Historisk Tidsskrift, 80 (1980), ("American Socialism and Labor Movement in the Beginning of the Century," Danish Historical Review, 80 (1980).

2 Belleville Trades and Labor Assembly. Minutes of Meetings, 1902-1922. Illinois State Historical Library, Springfield.

3 Feb. 21, 1911.

4 Oct. 18, 1910.

5 Oct. 19, 1915.

6 June 21, 1910. 
7 Feb. 6, 197. March 7, 1916. Feb. 1, 1916. Dec. 15, 1914. Nov. 3, 1914. Nov. 7, 1911 and succeeding meetings. March 5, 1912.

8 A number of propositions for improving working conditions were also discussed in Belleville, like the workers' compensation and employers' liability law, women's ten hour law, anti-injunction law, etc.

9 Haywood, leader of the IWW, was kidnapped into Idaho to stand trial for an alleged bombing. The kidnapping aroused labor protest, but in downstate Illinois IWW was not popular among the workers.

10 March 5, 1912. Feb. 6, 1912. Feb. 6, 1912.

11 Jan. 18, 1916.

12 Dec. 19, 1911. Author's own emphasis.

13 March 5, 1912.

14 Dec. 5, 1911. The Sherman Anti-Trust Law was interpreted as including labor organizations as well. In 1914 the Clayton Act declared unions and the strike weapon to be legal, although the courts in many cases were inclined,to judge otherwise.

15 Oct. 18,1904 .

16 Nov. $6, .1906$.

17 Oct. $20,1908$.

18 Oct. 18, Nov. 1, 1910.

19 March 21, 1911.

20 Tan. 6, 1914.

21 Aug. 1, 1916, Oct. 3, 1916. Aug. 29, 196.

22 Aug. 1, 1916 and all meetings to Nov .21, 1916.

23. I have not had access to figures that could illustrate the actual percentage of the organized workers of the electorate, but the zeal displayed by the individual candidates to obtain the endorsement of the labor unions idicates that they must have been regarded as important. Despite the efforts to unite labor's vote behind selected candidates, it does not preclude that they were in vain.

24 Jan. 18, 1916. May 16, 1916.

25 Aug. 7, 1917.

26 Sept. 18, 1917.

27 Feb. 5, 191. Feb. 19, 1918.

28 Feb. 19, 1918.

29 March 19, 1918.

30 This impression supports the thesis of Yellowitz and latest John Buenker that progressive politics as supported by the workers, thus meliorating the idea of exclusive middleclass aherence. Irwin Yellowitz, Labor and the Progressive Movement in New York State, 1897-1916. (N.Y. 1965.) John Buenker, Urban Liberalism and Progressive Reform (N.Y. 1973). 